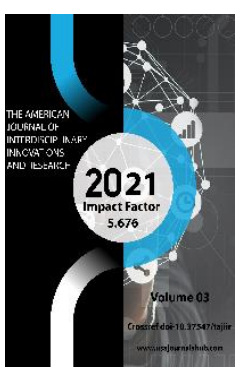

\title{
Genius Commander: Amir Temur
}

\section{Nurkulova R.R.}

Associate Professor, Honored Worker Of Public Education Of The Republic Of Uzbekistan, Department Of "Methods Of Teaching History", Faculty Of "History", Jizzakh State Pedagogical Institute Named After A.Qodiri, Uzbekistan

\footnotetext{
Copyright: Original content from this work may be used under the terms of the creative commons attributes 4.0 licence.
}

\section{ABSTRACT}

In this scientific article, an attempt was made to cover the activities of Sahibkiran Amir Temur as a great statesman and a skillful commander on the basis of historical sources. The place of Amir Temur in the history of the peoples of the world and Central Asia was covered.

\section{KEYWORDS}

Amir Temur, the great statesman, genius commander, Amir and Tokhtamishkhan, Yildirim Boyazid, Ibn Arabshah, R.G. de Clavijo, Sh.A. Yazdi, N.Shomiy, the Battle of Ankara, Timur and the Present.

\section{INTRODUCTION}

Amir Temur was a great medieval statesman, a famous commander, the founder of a strong centralized state, a patron of science and culture. He took a worthy place in world history as a great statesman and a skillful commander. 
Amir Temur sang the glory of his homeland and nation. He elevates the centralized state he founded to a higher level materially and culturally. He was praised in his time as "... the owner of the star of great happiness, the benevolent, humble sun, the mighty sun of the Turkish-Turkish state and the glorious king" [1].

As Ibn Arabshah, a historian of the time of Amir Temur, wrote: "The Seven Climates are the Sahibkiran, the one who rules the land and water, the jewel of kings and sultans" [2].

Amir Temur ibn Amir Taragay was born on April 9, 1336 in the village of Khoja Ilgor (now Yakkabag district) near the city of Kesh (Shahrisabz).

From a young age, under the supervision of special coaches, he mastered the skills of horseback riding, hunting, and archery. At the same time, Amir Temur grew up to be a skilled rider and a brave warrior.

\section{THE MAIN FINDINGS AND RESULTS}

Amir Temur was a man of natural calmness, deep thinking, extremely intelligent, strongwilled, and quick to understand the abilities and sincerity of people. That's why, as a teenager, he was surrounded by his peers and colleagues, who took part in military exercises and competitions. Later, soldiers emerged from among them.

The historian Ibn Arabshah describes Amir Temur as follows: "Timur is tall, tall, erect, as if he is a descendant of ancient heroes, broadforeheaded, big-headed, very strong and strong, of great height, white-faced, but spotless, not wheat-colored, strong arms and legs, shoulders His fingers were wide, his feet were thick, his legs were fat, he was tall, he was bald, his right leg was lame, his eyes were two candles, and his joy was indistinguishable" [2, p. 65].

As Ibn Arabshah described, Amir Temur was capable and powerful, and even when he was riding a horse, his right arm and leg were not noticeable.

Often in his meeting there would be no obscene words, no bloodshed, no captivity, no robbery, and no insults against his aunt. Amir Temur was fearless, courageous, obedient to brave people, liked the brave, courageous and brave.

Brave and courageous, brave and courageous Amir Temur defeated Amir Hussein in Balkh in the spring of 1370 and became the sole ruler of Mowaraunnahr. Now the main goal of all its activities is to unite the regions of the country, to create a single centralized state. He was well aware that without it it is impossible to achieve the development of the country, to raise its prestige in the world.

Amir Temur's main goal was to liberate the country from Mongol oppression, political disintegration and conflict as a result of several years of bloody and bloodless struggles for the establishment of a centralized state, important events and, in due course, successful use of diplomatic relations. The regions of Mowaraunnahr and Khorasan were united and managed to establish a single centralized state.

Sahibkiran devoted all his activities to the material and cultural up-liftment of his state and to its security.

The country's capital, Samarkand, was named "arus al-owasim" ("bride of the capitals of the world") or "al-Madiynat az-arqa" ("Blue City"), as the Egyptian historian al-Sayyid Faraj wrote in The Great Commander Temur [3].

During the reign of Amir Temur, the capital Samarkand became one of the most beautiful cities. At the same time, trade, handicrafts, science and culture flourished in Movaraunnahr during the Sahibkiran period.

As well as being the founder of a centralized state and a vast empire, Sahibkiran was one of the most famous commanders of the Middle 
Ages. Military history considers Timur to be one of the greatest military leaders in medieval Asia. His military prowess was demonstrated in two ways: in the reorganization of military units, and in the command of the army" [4, p. 453].

Amir Temur formed strong military units that were not divided into tribes. In fact, its invincibility was due to these military units. Realizing this, Amir Temur transferred the warriors to the army according to a certain plan. He was able to subdue power to reason. Amir Temur means his victory is a state of mind, submission to the will of the enemy, capture of initiative. He realized that a ruler whose spiritual prestige was below his power was miserable, and went on to overcome it. In his view, the state was to be enriched for its own well-being, and the army was to be a reliable base.

Amir Temur introduced new regimes in the army and controlled them. He inspired the idea of patriotism by believing in the Great Commander in the warrior's faith, and by developing in him the ability to stand upright even to death. He respected the warrior's courage and demeanor along the way.

In Sahibkiran's “Tuzuklari" (Rules of Sahibkiran), "I raised the ranks of the heroes of the Sipohi, giving the brave with a special fire, belt and scattering ... I always kept my Sipohi ready for battle, I paid their salaries on time without asking" [5, p. 65].

Amir Temur was with his troops in battles and taught them military secrets.

Sahibkiran was a skillful and wise military strategist of his time, who knew that war was the last and final means.

Amir Temur fought because his strategy was based on the strong training of the army, and he would surprise the enemy by making unexpected decisions during the battle.
Sahibkiran was surprisingly military talented. Along with building a strong and disciplined army, he was able to manage the troops wisely during the battle, to decide the fate of the battle, to deploy troops quickly, to eliminate existing obstacles and obstacles, and to keep the fighting spirit in the army high.

The English historian Hilda Hookham, in her book "The Ruler of the Seven Climates", praised his military talent: “... he was a master of military tactics and skillfully used every opportunity to achieve his goal. The basis of his military power was a loyal, select, cavalry force" [6, p. 13].

Indeed, Amir Temur achieved victories with the power of his military potential and even higher military genius.

Sahibkiran's army consisted of tens, hundreds, and thousands of divisions, each of which was led by a military chief. Depending on the number of divisions, they were subordinate to each other. The pieces differed from each other in terms of clothing, flags and banners.

In Amir Temur's "Tuzuklari”: “... who, from the original armies, died in battle, and when ten men were gathered, whichever of them was more courageous, with the consent and approval of the other nine, elected him commander and named his horse the captain" [5, p. 69], he wrote.

Thus, centurions and commanders were appointed from experienced, refined warriors.

Amir Temur paid great attention to the position of emirate: “... I ordered three hundred and thirteen people to be emirates, because they are pure, pure-blooded, intelligent, brave, courageous, enterprising, vigilant, careful, thinking ahead and behind was" [5, p. 78], he wrote in his Statutes.

All the emirs of the Sahibkiran who had the above qualities were skilled commanders and men who defeated the enemy. 
Amir Temur's powerful army was led by the famous commanders of his time, Amir Bayan Sulduz, Amir Kaykhus, Boyazid Jalair, Muhammad Shah Bukhari, Hizr Yasavuri Sher Bahrom, Siddiq Barlos and others.

According to Ibn Arabshah, a historian of Amir Temur's time, there were women in Sahibkiran's army, "They fought valiantly against the men of the enemy, and in battle they did more than skilled men in spear, sword, and archery" [2, p. 99].

The owner has always paid great attention to women and put their respect in place. Amir Temur has always valued strong, brave and courageous people.

It should be noted that in any situation, even in difficult combat situations for himself, Hazrat Amir Temur followed the criteria of justice, tried to resolve the issue through war. However, the khan of the Golden Horde, Tokhtamishkhan, forgetting the goodness of his valine, repeatedly attacked the borders of the Sahibkiran state. Therefore, Amir Temur was forced to march against him several times. In the battle near Terek, Amir Temur once again proved that he was not only a brave and resourceful commander, but also a skilled politician. With his victory over Tokhtamishkhan in 1395, Sahibkiran abolished the powerful position of the Golden Horde. In this way, Amir Temur served the people of Russia and ensured the security of his country.

The biggest of Amir Temur's victories was his victory over the mighty Sultan of Turkey, Yildirim Boyazid, in the battle near Ankara.

Amir Temur sent letters to several Turkish sultans, Bayazid Yildirim, explaining his purpose. In his letter: "Sultan Ahmad and Qara Yusuf cited the reason for this as the fact that they both fled from the sword of their swords, that they were a source of corruption, a catastrophe for the countries and a calamity for the slaves. They have taken refuge with those who are with them under your protection ... Therefore; you should not give them shelter, but let them go" [7, p. 255]

In his letter, Amir Temur tried to prevent a war between two Muslim rulers, the two great powers of the time.

On the contrary, Yildirim responded to Boyazid Sahibkiran in such a way that he would put any ruler on the horse of anger and hatred. In his letter, Yildirim Boyazid wrote to Sahibkiran, “... If you do not come to us, let your wives be divorced three times. If you come to my country and I run away without a decisive war against you, then my wives will be divorced three times" [7, pp. 258-259]. Yıldırım Boyazid's mention of women was a great mistake for the Muslim ruler, because in the Turkic peoples, insulting women was a grave sin. Sahibkiran, who read the above-mentioned letter, was forced to say, "Ibn 'Uthman is insane and stupid" [7, pp. 258-259].

By 1402, such a relationship had strained the relationship between Amir Temur and Boyazid, making it clear that it would be a decisive battle between the two.

Hazrat Amir Temur approached every battle with great seriousness and responsibility and carefully prepared. The day the war began was a top secret. Sahibkiran studied the opposite side in detail through special people - "spies". He was able to skillfully use various opportunities and tactical methods in time during the battle. On top of that, on the eve of the battle, he ordered the enemy side, through his men, to condemn his opponent.

Sahibkiran Yildirim also used his diplomatic skills as he prepared for war against Boyazid. To this end, he held talks with the ambassadors of Byzantium, France, Genoa and Venice. Yıldırım also managed to leave Boyazid alone diplomatically. On the eve of the war, Yildirim put Boyazid in a difficult situation. Sohabkiran Yildirim made great military preparations for the war with Boyazid. Before the battle, Amir Temur's army had more than 100,000 cavalry, 
300,000 infantry and 20 military elephants. Amir Temur's army also had artillery that had not been used in battles before.

Yıldırım Boyazid also marched towards Ankara with his 200,000 infantry and 80,000 cavalry in the center. Apparently, Sahibkiran's army had a great military advantage over the opposition army. Thus, on July 28, 1402, Amir Temur ordered the battle. It was one of the biggest clashes in world history.

At that time, Europe could not stand against Yildirim Boyazid. Therefore, looking at Amir Temur as a savior, he had high hopes for his victory. Amir Temur was the first in the history of martial arts to divide the army into seven parts, three of which were independent: the center, that is, the heart, the burongor, the juveniles; four: two foreheads and two kanbuls were subordinate parts. The peculiarity of this deployment was that its wing parts were much stronger than the central part [8, p. 31]. According to the medieval historian Sh.A.Yazdi, Amir Temur was the first to introduce the order of division of the army into seven divisions and used it in battle.

In the battle near Ankara, Sahibkiran Amir Temur demonstrated that he had unparalleled military potential and was a skilled soldier.

.... The battle began when the right-wing Serbian cavalry clashed with Prince Shahrukh's cavalry. As the left wing began to retreat, Timur threw the Turkmen cavalry to the left wing. Muhammad Sultan's army was thrown to the right wing under the command of Prince Shahrukh. During this period, when the Yanchars in Boyazid's central army came under heavy attack, Sultan Hussein struck them hard. With Boyazid throwing all his reserve troops into battle, the military superiority was on the side of Amir Temur. At the same time, Sahibkiran threw his artillery and military elephants into battle. The battle was extremely fierce, sometimes it was, and sometimes it was dominated by this side. However, the outcome of the battle was decided by Timur's favorite tactic - distraction. In the battle of Ankara, Amir Temur also used the methods of military skill used in other battles, such as correctly determining the main directions of the blow, striking the enemy from the unexpected side, constantly threatening the enemy, stunning him. Finally, Yildirim Boyazid and his two sons, who were terrorizing the whole of Europe, were taken prisoner in battle.

In the great battle with Yildirim Boyazid, Hazrat Amir Temur once again proved that he was a genius soldier, a wise strategist. Historians liken this battle to Alexander the Great's victory over Darius and Napoleon's victory over Frederick the Great.

Indeed, in this battle Boyazid lost the victory, the huge army, the mighty empire. Sahibkiran, on the other hand, achieved a great historical victory and saved Europe from the tyranny of the Turks, fulfilling his task of salvation before them. Amir Temur has a worthy place in the history of world martial arts with a great commander and skilful military leadership. Sahibkiran's military skills have been taught and studied for many years in military academies of countries such as England, France, and Russia.

\section{CONCLUSION}

So, those who have written about the image and history of Amir Temur give him a number of descriptions, such as "Ruler of the Seven Climates", "Jewel of kings and sultans", "genius statesman", "great commander", "skilled soldier". The 35-year reign of Hazrat Amir Temur was aimed at the material and spiritual development of his homeland, raising it to a higher level, ensuring its security. The great Sahibkiran state in its time took a worthy place among the countries of the world with its potential and military power. Sahibkiran glorified the power of his state and the glory of his nation to the world. 
During the years of independence, the image of Amir Temur became a symbol of the Motherland and the nation.

The material, cultural and spiritual heritage left by Amir Temur in our history is in harmony with our lives today, and they play an important role in solving and implementing the problems facing us. We are building a renewed Uzbekistan based on the characteristics of our nation, our national values, the experience of developed countries and universal beliefs.

\section{REFERENCES}

1. Sh.A.Yazdiy. (1996). Zafarnoma. Tashkent: “Kamalaka”. (Ш.А.Яздий. Зафарнома. Т.: “Камалака”, 1996.)

2. Ibn Arabshoh. (1992). History of Amir Temur. Book II. - Tashkent: "Mehnat". (Ибн Арабшох. Амир Темур тарихи. II китоб. Т.: “Мехнат”. 1992.)

3. Ubaydulla Uvatov. (1997). In the eyes of Sahibkiran Arab historians. - Tashkent: Sharq. (Убайдулла Уватов. Сохибқирон араб муаррихлари нигохида. Т: “Шарқ”, 1997.)

4. History of the Uzbek SSR. Volume I. Toshkent: Publishing house. Fan, 1967. - p. 453. (История Узбекской ССР. Том І. Тошкент. Изд-ва. “Фан”, 1967, стр 453.)

5. Timur's rules. - Tashkent: G. Gulom Publishing House. 1991. - p. 65. (Темур тузуклари. Т.: “Ғ.Ғулом” нашриёти. 1991. 65-бет.)

6. Khilda Hukxem. (1995). Seven climate rulers. - Tashkent: “Justice". - p. 13. (Хильда Хукхэм. Етти иқлим хукмдори. Т.; “Адолат”. 1995. 13-бет.

7. Ibn Arabshoh. (1992). History of Amir Temur. 1 book. - Tashkent: "Labor". - p. 255. (Ибн Арабшох. Амир Темур тарихи. 1 китоб. -Т.: “Мехнат”, 1992. 255-бет.)

8. A.Muhammadjonov. (1996). Timur and the Timurid Empire. - Tashkent: "Qomuslar" editor-in-chief. - $\quad 31$. (А.Мухаммаджонов. Темур ва
Темурийлар салтанати. Т.: “Қомуслар” бош тахририяти. 1996. 31-бет.)

9. Mirziyoev Sh.M. (2017). We will build our great future together with our brave and noble people. - Tashkent: "Uzbekistan". (Мирзиёев Ш.М. Буюк келажагимизни мард ва олижаноб халқимиз билан бирга қурамиз. - Т.: “Ўзбекистон”, 2017.)

10. Askarov A. (1992). Tasks of historical science in the conditions of independence of Uzbekistan: (Social sciences of Uzbekistan). №7,8. (Асқаров А. Ўзбекистон мустақиллиги шароитида тарих фанининг вазифалари: (Ўзбекистон ижтимоий фанлар) 1992. №7,8.)

11. Azimov E. (1996). The reign of Amir Temur. - Tashkent: "G. Gulom" publishing house. (Азимов Э. Амир Темур салтанати. -Т.: “Ғ.Ғулом" нашриёти, 1996.)

12. N.Shomiy. (1996). Zafarnoma. - Tashkent: “Uzbekistan”. (Н.Шомий. Зафарнома. -Т.: “Ўзбекистон”, 1996.)

13. Muminov I.M. (1991). The place and role of Amir Temur in the history of Central Asia. Tashkent: "Fan". (Мўминов И.М. Амир Темурнинг Ўрта Осиё тарихида турган ўрни ва роли. -Т.: “Фан”, 1991.)

14. Muhammadjonov A. (1991). Timur and the Timurid Empire. - Tashkent: "Editor-inChief of Laws". (Мухаммаджонов A. Темур ва темурийлар салтанати. - Т.: “Қонунлар бош тахририяти". 1991.)

15. Nosirov U, Nurqulova R. (2014) To understand Amir Temur is to understand oneself. - Tashkent: "Tafakkur”. (Носиров У, Нурқулова Р. Амир Темурни англашўзликни англашдир. -Т.: “Тафаккур”, 2014.)

16. Marcel Brion. (2015). Who am I? Sahibqiran - Jahongir. - Tashkent: "The new generation”. (Марсель Брион. Мен ким Сохибқирон - Жахонгир. Т. "Янги аср авлоди". 2015.)

17. Guide Gonzales de Clavico. Diary of a trip to Samarkand - Amir Temur Palace. (14031406) - Tashkent: “Uzbekistan”, 2016. (Гуиде Гонзалес де Клавико. 
The American Journal of Interdisciplinary Innovations and Research (ISSN-2642-7478)

Published: April 22, 2021 | Pages: 21-27

Самарқандга - Амир Темур саройига саёхат кундалиги. (1403-1406 йиллар) -Т.: “Ўзбекистон", 2016.)

18. Uvatov U. (1997). In the eyes of Sahibkiran Arab historians. - Tashkent: "East". (Уватов У. Сохибқирон араб муаррихлари нигохида. Т. “Шарқ”. 1997.) 